JOURNAL

OF TOURISM

AND ECONOMIC
Journal of Tourism and Economic Vol.4, No.1, 2021, Page 60-72

ISSN: 2622-4631 (print), ISSN: 2622-495X (online)

Email:jurnalapi@gmail.com

Website: http://jurnal.stieparapi.ac.id/index.php/JTEC

DOI: https://doi.org/10.36594/jtec.v4i1.111

\title{
STRATEGI PEMASARAN FOOD AND BEVERAGE UNTUK MENINGKATKAN PENJUALAN PADA MASA PANDEMI COVID-19 DI CAVINTON HOTEL YOGYAKARTA, INDONESIA
}

\author{
Lutfi Hendriyati \\ Akademi Pariwisata Yogyakarta \\ lutfihendriyati.slamet@gmail.com \\ Ihsan Budi Santoso \\ Akademi Pariwisata Yogyakarta \\ rasahgetun86@gmail.com
}

\begin{abstract}
The Covid19 pandemic corona virus in Indonesia was first detected on March 2, 2020. The Covid19 outbreak had a very devastating impact on the world Various industries are experiencing a slump, especially in the tourism sector. The weakening of the tourism industry in Indonesia such as Bali, Yogyakarta, Lombok has experienced a very drastic decline. The method used in this research is descriptive qualitative. Through this method, the writer tries to reveal the Food and Beverage marketing strategy during the covid 19 period at the Cavinton hotel in Yogyakarta. The analysis tool used is SWOT analysis to formulate a strategy for identifying various factors based on the researcher's knowledge and understanding. SWOT analysis is used to formulate a strategy through maximizing strength and opportunities and simultaneously minimizing weaknesses and threats. The results of research due to Covid19 make public awareness of cleanliness, health, safety and environmental sustainability very large. The decline in the tourism sector due to social distance caused the hotel business to decline so that Food and Beverage used various innovations and strategies to survive the Covid19 Pandemic, Public interest in food and delivery services is increasingly in demand, with the increasing transmission of covid19 making people limit themselves from leaving the house.
\end{abstract}

Keywords: Hospitality, Food and Beverage, Marketing, Covid19 


\begin{abstract}
ABSTRAK
Virus corona Pandemi Covid19 di Indonesia pertama kali terdeteksi pada 2 Maret 2020. Mewabahnya Covid19 membawa dampak yang sangat dasyat di dunia. Berbagai Industri mengalami kelesuan terutama pada bidang Pariwisata. Melemahnya industri Pariwisata di Indonesia seperti, Bali, Yogyakarta, Lombok mengalami penurunan yang sangat drastis. Metode yang digunakan dalam Penelitian ini adalah deskriptif kualitatif. Melalui metode ini penulis mencoba mengungkapkan strategi pemasaran Food and Beverage pada masa covid19 di hotel Cavinton Yogyakarta. Alat analisis yang digunakan menggunakan Analisis SWOT digunakan untuk merumuskan suatu strategi atas identifikasi berbagai faktor berdasarkan pengetahuan dan pemahaman peneliti. Analisis SWOT digunakan menyusun strategi melalui memaksimalkan Kekuatan (strenght) dan peluang (Opportunity) dan secara bersamaan meminimalkan kelemahan (Weaknesses) dan ancaman (Threat). Hasil penelitian Akibat Covid19 membuat kesadaran Masyarakat akan kebersihan, kesehatan, keselamatan dan kelestarian lingkungan sangat besar, Terpuruknya sektor Pariwisata akibat social distance menyebabkan bisnis perhotelan terpuruk sehingga Food and Beverage menggunakan Berbagai Inovasi dan Strategi agar dapat bertahan pada masa Pandemi Covid19, Minat Masyarakat terhadap makanan layanan antar semakin diminati, dengan meningkatnya penularan covid19 membuat masyarakat membatasi diri untuk keluar rumah.
\end{abstract}

Kata kunci : Perhotelan, Food and Beverage, Pemasaran, Covid9 


\section{PENDAHULUAN}

Virus corona Pandemi Covid-19 di Indonesia pertama kali terdeteksi pada 2 Maret 2020. Mewabahnya Covid-19 membawa dampak yang sangat dasyat di dunia. Berbagai Industri mengalami kelesuan terutama pada bidang Pariwisata. Melemahnya industri Pariwisata di Indonesia seperti, Bali, Yogyakarta, Lombok mengalami penurunan yang sangat drastis. Menurunnya Jumlah Wisatawan yang datang Ke Yogyakarta mengakibatkan Occupancy hotel di Yogyakarta mengalami Pernurunan drastis. Virus dapat berpindah secara langsung melalui percikan batuk atau bersin dan napas orang yang terinfeksi yang kemudian terhirup orang sehat. Virus juga dapat menyebar secara tidak langsung melalui benda-benda yang tercemar virus akibat percikan atau sentuhan tangan yang tercemar virus. Virus bisa tertinggal di permukaan benda-benda dan hidup selama beberapa jam hingga beberapa hari, namun cairan disinfektan dapat membunuhnya.

Selama masa pandemi covid 19 dan adanya Pembatasan Sosial Berskala Besar (PSBB) di berbagai wilayah, Masyarakat dihimbau untuk tetap tinggal dirumah dan menghindari bepergian atau keluar rumah untuk sesuatu yang tidak mendesak. Semua kegiatan dilakukan dirumah termasuk bekerja dan bersekolah. Hal ini membuat Manajemen harus memutar otak bagaimana caranya agar bisnisnya bisa terus bernapas di tengah pandemi. Manajemen harus beradaptasi dan berinovasi untuk merespons tantangan baru ini. Manajemen harus memiliki strategi pemasaran agar hotel tetap dapat menghasilkan pendapatan dengan memanfaatkan potensi yang ada di hotel. Menurut American Marketing Association (AMA) , Pemasaran / Marketing adalah aktivitas, serangkaian institusi, dan proses menciptakan, mengomunikasikan, menyampaikan, dan mempertukarkan tawaran yang bernilai bagi pelanggan, klien, mitra, dan masyarakat umum. Di masa covid 19 ini hotel diperlukan strategi dalam mencari pangsa pasar, Bagaimana mengelola keterbatasan menjadi peluang usaha, Food beverage salah satu departemen yang dapat diandalkan pada saat sulit seperti ini , Food and Beverage departement merupakan bagian hotel yang mengurus dan bertanggung jawab terhadap kebutuhan makanan dan minuman serta kebutuhan lain yang terkait, dari para tamu yang tinggal maupun yang tidak tinggal di hotel tersebut dan dikelola secara komersial serta profesional.

Hotel Cavinton Yogyakarta adalah salah satu hotel di daerah istimewa Yogyakarta dengan kualifikasi bintang empat. Hotel yang berlokasi di Jl. Letjend Soeprapto No. 1 Ngampilan Yogyakarta memiliki tiga restoran yaitu Shambala all day dinning sebagai restoran utama, Amarta coffe and tea dan yang terakhir sky lounge and bar yang menjual minuman cocktail dan moktail yang berada di lantai delapan. Dalam menghadapi masa krisis ini perusahaan perlu mengenali kekuatan dan kelemahan perusahaan, hal ini dapat membantu perusahaan dalam menetapkan strategi pemasaran mampu memanfaatkan peluang dan kekuatan perusahaan

khususnya pada Food and Beverage Departement.

Berdasarkan latar belakang diatas masalah tersebut maka rumusan masalah dalam penelitian tersebut sebagai berikut :

1. Bagaimana analisis lingkungan eksternal dan internal and Beverage Departement di Hotel Cavinton Yogyakarta

2. Bagaimana kekuatan, kelemahan, peluang dan ancaman Food and Beverage Departement di hotel Cavinton Yogyakarta?

3. Bagaimana strategi Pemasaran Food And Beverage hotel Cavinton yogyakarta selama masa Pandemi 


\section{TINJAUAN LITERATUR}

\section{Pemasaran}

Menurut American Marketing Association (AMA) , Pemasaran / Marketing adalah aktivitas, serangkaian institusi, dan proses menciptakan, mengomunikasikan, menyampaikan, dan mempertukarkan tawaran yang bernilai bagi pelanggan, klien, mitra, dan masyarakat umum.Menurut Kotler dan Keller (2016: 27) marketing is a societal process by which individuals and groups obtain what they need and want through creating, offering, and freely exchanging products and services of value with others. Pemasaran adalah sebuah proses kemasyarakatan dimana individu dan kelompok memperoleh apa yangmereka butuhkan dan ingin menciptakan, menawarkan, dan secara bebas mempertukarkan produk dan jasa yang bernilai dengan orang lain.

Dari definisi para ahli diatas dapat disimpulkan bahwa pemasaran adalah salah satu kegiatan pokok yang perlu dilakukan oleh perusahaan baik itu perusahaan barang atau jasa dalam upaya untuk mempertahankan kelangsungan hidup usahanya. Hal tersebut disebabkan karena pemasaran merupakan salah satu kegiatan perusahaan, di mana secara langsung berhubungan dengan konsumen. Maka kegiatan pemasaran dapat diartikan sebagai kegiatan manusia yang berlangsung dalam kaitannya dengan pasar kegiatan usaha yang harus berorientasi ke pasar atau konsumen.

\section{Strategi pemasaran}

Strategi pemasaran memberikan arah dalam kaitannya dengan segmentasi pasar, identifikasi pasar sasaran, positioning dan bauran pemasaran. Bauran pemasaran (marketing mix) terdiri dari empat elemen yaitu produk, harga, promosi,tempat. (Atmoko, 2018)

Strategi adalah sebuah tindakan aksi atau kegiatan yang dilakukan seseorang atau perusahaan untuk mencapai sasaran atau tujuan yang telah ditetapkan (David 2011:18) dari pendapat diatas dapat disimpulkan bahwa Kegiatan yang dilakukan seseorang untuk mencapai tujuan melalui aksi atau kegiatan terhadap perubahan lingkungan dan persaingan mealui segmentasi pasar, identifikasi pasar sasaran,positioning dan bauran pemasaran

Menurut Kotler dan Amstrong (2012:92) "Marketing mix is good marketing tool is a set of products, pricing, promotion, distribution, combined to produce the desired response of the target market" dalam bauran pemasaran terdapat seperangkat alat pemasaran yang dikenal dalam istilah 4P, yaitu product (produk), price (harga), place(tempat atau saluran distribusi), dan promotion (promosi), sedangkan dalam pemasaran jasa memiliki beberapa alat pemasaran tambahan seperti people (orang), physical evidence (fasilitas fisik), dan process (proses), sehingga dikenal dengan istilah 7P. maka dapat disimpulkan bauran pemasaran jasa yaitu product, price, place, promotion, people, physical evidence, and process.

\section{Food and Beverage}

Food and Beverage Department berasal dari bahasa Inggris yang berarti bagian makanan dan minuman. Oleh sebab itu bagian ini adalah bagian yang bertanggung jawab atas aspek makanan dan minuman. Aspek makanan dan minuman lebih mengutamakan faktor cita rasa dan mutu pelayanannya. Ini merupakan hal yang sangat relatif dalam penilaian dan penerimaan setiap orang dengan demikian di dalam penanganannya diperlukan keahlian dan keterampilan yang bersifat khusus.

Menurut I Gede Agus Mertayasa dalam bukunya Food \& Beverage service operational(2012:2). Food \& Beverage Departement merupakan salah satu department yang ada dihotel. Departemen ini termasuk departemen yang sangat penting sebab dapat menghasilkan atau mengdatangkan keuntungan. Tamu yang 
tinggal di hotel tidak saja memerlukan tempat tidur(kamar) tetapi juga memerlukan makanan dan minuman yang akan dilayani oleh bagian tata hidang atau F\&B Service.

Berdasarkan pengertian dari para ahli diatas dapat disimpulkan bahwa departement F\&B adalah salah satu departement yang bertugas dibidang makanan dan minuman baik dari segi mengelola sampai menghidangkan kepada tamu. Secara umum departement food and beverage dibagi menjadi dua departemen/bagian yang pertama Departement Food And Beverage Service atau bisa disebut Seksi restoran adalah Department yang selalu berhubungan dengan pelayanan dan penyajian makanan dan minuman kepada tamu serta memberikan pelayanan dengan baik, department ini akan selalu berhubungan dengan tamu. Prihandini dan Mayasari (2019) mengemukakan bahwa Restoran merupakan industri dimana didalamnya memiliki beberapa outlet dan bagian yang memberikan pelayanan kepada tamu yang datang dengan baik dan sopan, Restoran juga disediakan untuk mereka yang sedang bepergian jauh/dekat, Restoran juga memiliki fyngsi seperti Pelayanan kamar, buffet service (Pelayanan makan prasmanan) dan acara hotel lainnya yang memerlukan jasa dari departemen.

Dan yang kedua adalah Departement Food And Beverage Production atau Seksi kitchen adalah Departement yang bertugas untuk memasak dan menyiapkan makanan dan minuman yang layak untuk dihidangkan kepada tamu, departement F\&B produk merupakan departement yang tidak melakukan kontak langsung dengan pengunjung/tamu.

Dalam industri jasa makanan dan minuman saat ini telah berkembang demikian pesat dan telah menyebar kedalam kehidupan manusia dimana pun dia berada, dan hampir menjamah setiap jenis bisnis yang ada seperti, hotel, restoran, kantin industri, kantin rumah sakit, kereta api, maskapai penerbangan, maupun pedagang kaki lima dan indutri lain yang ada disekitar kita.

Fungsi dasarnya adalah untuk melayani makanan dan minuman, tujuan utamanya adalah untuk mencapai kepuasan tamu dan keuntungan perusahaan, disamping untuk kegiatan sosial lainya. Kebutuhan yang dapat memuaskan dapat dirasakan oleh pelanggan pada saat melakukan pembelian dan merasa Puas atas pelayanan yang diberikan, Suasana yang bersahabat dan pengalaman yang dirasakan oleh pelanggan , kemudian adanya kebutuhan untuk meningkatkan harga diri atau prestige.

\section{Penjualan}

Penjualan merupakan kegiatan bidang pemasaran dalam menjual barang produksinya kepada konsumen yang dilaksanakan perusahaan dalam menyampaikan barang produksinya agar dapat dinikmati oleh konsumen (Didik Darmadi, 2013). Sedangkan menurut Thamrin Abdullah dan Francis tantri (2016,3) Penjualan adalah salah satu bagian dari keseluruhan sistem pemasaran. volume penjualan merupakan jumlah total yang dihasilkan dari kegiatan penjualan barang. Semakin besar jumlah penjualan yang dihasilkan perusahaan, semakin besar kemungkinan laba yang akan di hasilkan perusahaan Amalinya, 2017)

\section{Beberapa usaha untuk meningkatkan Penjualan}

Penjualan merupakan kegiatan menyampaikan kebutuhan yang telah dihasilkan pada mereka yang diperlukan dengan imbalan merurut harga yang ditentukan atas persetujuan bersama. Menurut Kurniadi (2010:35-36), ada beberapa usaha untuk meningkatkan volume penjualan, di antaranya adalah:

1. Menjajakan produk dengan sedemikian rupa sehingga konsumen melihatnya. 
2. Menempatkan dan pengaturan yang teratur sehingga produk tersebut akan menarik perhatian konsumen.

3. Mengadakan analisa pasar.

4. Menentukan calon pembeli atau konsumen yang potensial.

5. Mengadakan pameran.

6. Mengadakan discount atau potongan harga.

\section{Pandemi Covid-19}

Peristiwa menyebarnya Penyakit koronavirus 2019 (bahasa Inggris: coronavirus disease 2019, singkatan dari COVID-19) di seluruh dunia. Penyakit ini disebabkan oleh koronavirus jenis baru yang diberi nama SARS-CoV-2 (Gorbalenya, Alexander E. 2020).Wabah COVID-19 pertama kali dideteksi di Kota Wuhan, Provinsi Hubei, Tiongkok pada tanggal 1 Desember 2019, dan ditetapkan sebagai pandemi oleh Organisasi

Kesehatan Dunia (WHO) pada tanggal 11 Maret 2020.

Menurut Kementrian Kesehatan RI, Coronavirus merupakan keluarga besar virus yang menyebabkan penyakit pada manusia dan hewan. Pada manusia biasanya menyebabkan penyakit infeksi saluran pernapasan, mulai flu biasa hingga penyakit yang serius seperti Middle East Respiratory Syndrome (MERS) dan Sindrom Pernafasan Akut Berat/ Severe Acute Respiratory Syndrome (SARS). Coronavirus jenis baru yang ditemukan pada manusia sejak kejadian luar biasa muncul di Wuhan Cina, pada Desember 2019, kemudian diberi nama Severe Acute Respiratory Syndrome Coronavirus 2 (SARS-COV2), dan menyebabkan penyakit Coronavirus Disease-2019 (COVID-19).

Gejala umum berupa demam 38C, batuk kering, dan sesak napas. Jika ada orang yang dalam 14 hari sebelum muncul gejala tersebut pernah melakukan perjalanan ke negara terjangkit, atau pernah merawat/kontak erat dengan penderita COVID-19, maka terhadap orang tersebut akan dilakukan pemeriksaan laboratorium lebih lanjut untuk memastikan diagnosisnya.

Seseorang dapat terinfeksi dari penderita COVID-19. Penyakit ini dapat menyebar melalui tetesan kecil (droplet) dari hidung atau mulut pada saat batuk atau bersin. Droplet tersebut kemudian jatuh pada benda di sekitarnya. Kemudian jika ada orang lain menyentuh benda yang sudah terkontaminasi dengan droplet tersebut, lalu orang itu menyentuh mata, hidung atau mulut (segitiga wajah), maka orang itu dapat terinfeksi COVID-19. Atau bisa juga seseorang terinfeksi COVID-19 ketika tanpa sengaja menghirup droplet dari penderita. Inilah sebabnya mengapa kita penting untuk menjaga jarak hingga kurang lebih satu meter dari orang yang sakit.

\section{METODE PENELITIAN}

Metode penelitian ini menggunakan penelitian deskriptif kualitatif dengan menggunakan pendekatan Analisis SWOT. Menurut Mukhtar (2013: 10) metode penelitian deskriptif kualitatif adalah sebuah metode yang digunakan peneliti untuk menemukan pengetahuan atau teori terhadap penelitian pada satu waktu tertentu. Metode yang digunakan dalam Penelitian ini adalah deskriptif kualitatif. Melalui metode ini penulis mencoba mengungkapkan strategi pemasaran Food and Beverage pada masa covid 19 di hotel Cavinton Yogyakarta

Penulisan ini bertujuan untuk mengungkap fakta, keadaan, fenomena, variabel dan keadaan yang terjadi saat penulisan berjalan dan menyajikan sesuai apa adanya. Penelitian ini menafsirkan dan menyampaikan data sesuaai situasi yang terjadi, menyangkut hubungan antar variabel, perbedaan antar fakta, pengaruh suatu kondisi dan lain-lain. teknik pengumpulan data bersumber dari data primer, sumber-sumber data primer ( Sugiyono, 2017) yaitu: Adanya Pengamatan langsung, Metode observasi 
Pada penelitian ini observasi dilakukan dilakukan secara deskriptif, yaitu peneliti berusaha untuk mengamati, merekam, mencatat dan mendokumentasikan keadaan,Wawancara langsung yaitu proses tanya jawab dalam penelitian yang berlangsung secara lisan, dan adanya dokumentasi.

\section{Analisis SWOT}

Analisis SWOT adalah alat analisis yang digunakan untuk merumuskan suatu strategi atas identifikasi berbagai faktor berdasarkan pengetahuan dan pemahaman peneliti. Analisis SWOT digunakan menyusun strategi melalui memaksimalkan Kekuatan (strenght) dan peluang (Opportunity) dan secara bersamaan meminimalkan kelemahan (Weaknesses) dan ancaman (Threat). Analisis SWOT melihat faktor internal (kekuatan dan kelemahan) dan faktor eksternal (peluang dan ancaman) sehingga dari hasil analisis dapat diambil sebuah keputusan (Utama dan Mahadewi, 2012) untuk melakukan analisis SWOT pada strategi penjualan Food and Beverage untuk meningkatkan penjualan pada masa Pandemi Covid 19 di Cavinton Hotel untuk meningkatkan penjualan pada masa Pandemi Covid 19 di Cavinton Hotel Yogyakarta, maka matrix SWOT digunakan sehingga mudah dalam mengaplikasikan pada kondisi di Food and Beverage Hotel Cavinton pada masa pandemi covid-19.

\section{HASIL DAN PEMBAHASAN}

\section{Lingkungan Eksternal dan Internal Food and Beverage Cavinton Hotel Yogyakarta}

\section{Lingkungan Eksternal}

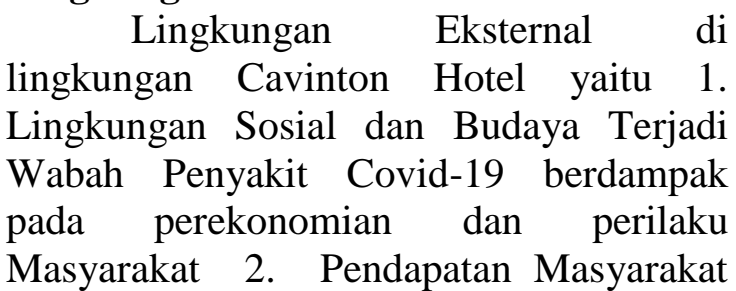

mengalami penurunan, banyak pengusaha dan pedagang mengalami kerugian, hal ini menyebabkan penurunan penjualan baik dari penjualan kamar maupun penjualan makanan dan minuman di Cavinton Hotel Yogyakarta. 3. Lingkungan Politik dan Hukum, Salah satu strategi Pemerintah dalam menekan penyebaran Covid-19 adalah dengan menetapkan kebijakan Pembatasan Sosial Berskala Besar (PSBB)..4. Persaingan Banyak usaha yang dilakukan oleh pelaku bisnis hotel, contohnya promosi menggunakan social media. Banyak pengusaha Hotel dan Restoran menggunakan fasilitas Social Media diantarnya Grab food, Go Food, Whatsapp group, Instagram dan lain lain.5. Tehnologi Perkembangan tehnologi membuat penjualan beralih dari luring menjadi daring. Misalnya penggunaan Grab food dan Go Food

\section{Lingkungan Internal}

Sedangkan Lingkungan internal di lingkungan Cavinton hotel Yaitu 1.Sumber Daya Manusia Karyawan Cavinton Hotel memiliki penampilan yang rapi dan ramah serta profesional dibidangnya.2. Manajemen Cavinton Hotel Melaksanakan Standard Operasional Procedure terkait pencegahan covid-19 agar masyarakat/ Tamu yang datang merasa aman dan nyaman. Keamanan dan kenyamanan merupakan faktor pendukung kegiatan masyarakat terutama di tempat tujuan wisata (Hendriyati, 2020), berbagai fasilitas dalam pencegahan covid 19 telah disediakan seperti, tempat cuci tangan dan sabun, handsanitizer, Masker, jaga jarak dan lain lain 3.Fasilitas Tersedianya fasilitas ballroom dan meeting room yaitu Prambanan room, Kalasan Junior Ballroom,ratu boko room, sambisari room, dawangsari room, plaosan room, gebang room, Barong room, small meeting room, fasilitas wifi dan lain sebagainya,membuat Ruangan ini banyak digunakan sebagai acara pernikahan, hajatan dengan memperhatikan Protokoler kesehatan. 


\section{Analisis SWOT}

Berdasarkan dari Pengamatan peneliti atas identifikasi berbagai faktor berdasarkan pengetahuan dan pemahaman peneliti,analisis SWOT digunakan menyusun strategi melalui memaksimalkan kekuatan (strenght) dan peluang (Opportunity) dan secara bersamaan meminimalkan kelemahan (Weaknesses) dan ancaman (Threat). Analisia SWOT Food And Beverage dalam meningkatkan penjualan di Hotel Cavinton Yogyakarta adalah Sebagai berikut:

\section{Kekuatan}

1. Mematuhi Protokoler Kesehatan berdasarkan buku panduan yang telah ditetapkan oleh Kementrian Kesehatan Republik Indonesia, Diantaranya menyediakan tempat cuci tangan/handsanitizer, memakai masker, menjaga jarak dan lain lain. Buku panduan protokol kesehatan ini merupakan turunan dari Keputusan Menteri Kesehatan Nomor HK.01.07/Menkes/382/2020 tentang Protokol Kesehatan bagi Masyarakat di Tempat dan Fasilitas Umum dalam Rangka Pencegahan dan Pengendalian COVID-19.

2. Lokasi Yang Strategis

Cavinton Hotel Yogyakarta terletak di pusat kota, dekat dengan Tujuan wisata seperti, keratonYogyakarta, Museum, Taman Pintar, Sentra Bakpia, wisata belanja Malioboro dan lain lain.

3. Meeting room

Memiliki Ruang Rapat untuk kegiatan MICE lengkap dengan seluruh perlengkapan yang dibutuhkan. Pada pandemi Covid 19 kegiatan meeting banyak dilakukan melalui via On line, sehingga ruangan meeting jarang digunakan. Tetapi pada masa pandemi ini ruangan meeting ternyata banyak digunakan pada acara pernikahan, mengingat bahwa di hotel telah menerapkan protokoler kesehatan sehingga ada rasa nyaman dan aman bagi tamu yang datang berkunjung/menginap.

4. Layanan Pesan Antar/ Delivery Order Manajemen Hotel Cavinton Memperkuat Tim F\&B dengan cara berjualan makanan dengan delivery order dengan melalui Sosial Media seperti Instagram, Group Whats App ataupun melalui website nya dengan nama Ipiring dengan sasaran pemasaran yaitu Masyarakat, pemerintahan, maupun perusahan dengan gratis biaya pengiriman. Dan tentu saja dengan protokoler kesehatan

5. Kemasan Yang menarik

Kemasan dalam Delivery Order makanan dan minuman dibuat sangat menarik,sehingga berkesan mewah dan hygenis.

6. Cafe dan Restoran

Dalam Memperluas usaha Food And Beverage dibuka Cafe yang terletak di area Bawah parkir atau tepatnya di sebelah selatan hotel Cavinton, Cafe ini menyediakan Coffee, teh, makanan, dan tiga restoran yaitu Shambala all day dinning sebagai restoran utama, Amarta coffe and tea dan yang terakhir sky lounge and bar yang menjual minuman cocktail dan moktail yang berada di lantai delapan

7. Karyawan

Karyawan sebelum bekerja di cavinton di cek Suhu tubuh, Menggunakan Masker/Field Shield, Cuci tangan memakai Sabun/Hand sanitizer, jadi Tamu yang datang merasa aman. Pelayanan yang baik dengan greeting dan Smile dalam melayani constumer.

8. Harga yang terjangkau

Harga makanan dan minuman sangat terjangkau oleh masyarakat untuk paket perorangan maupun paket keluarga. Dengan memberikan discount pada hari hari tertentu. Dan gratis biaya pengiriman 


\section{Kelemahan}

1. Transportasi

Kurangnya sarana transportasi untuk mengantarkan makanan dan minuman kepada pelanggan, sehingga sering mendapat keluhan dari pelanggan.

2. Branding Produk Hotel yang terkesan Mahal membuat orang enggan membeli apalagi pada masa pandemi seperti ini.

\section{Peluang}

1. Dengan adanya pandemi covid 19 dan adanya pembatasan sosial menyebabkan orang orang takut keluar rumah. Pandemi Corona menyebabkan perilaku yang baru bagi masyarakat. konsumen kini jauh lebih memperhatikan kesehatan terutama dalam memilih makanan. Sehingga tren makanan sehat dan tren masak di rumah dipilih banyak orang. Ini menjadikan peluang bagi Food And Beverage departement dalam mengembangkan produknya maupun pelayanannya.

2. Minat Masyarakat terhadap makanan layanan antar semakin diminati, dengan meningkatnya penularan covid-19 membuat masyarakat membatasi diri untuk keluar rumah.

3. Dukungan pemerintah terhadap bisnis Hotel dan Restoran pada masa pandemi ini. CHSE (Cleanliness, Health, Safety, and Environment) program dari Kementerian Pariwisata dan Ekonomi Kreatif (Kemenparekraf) yang disosialisasikan melalui pemerintah daerah kepada pelaku usaha sektor hotel dan restoran agar produk dan pelayanannya memenuhi syarat protokol kebersihan, kesehatan, keselamatan, dan kelestarian lingkungan.

\section{Ancaman}

1. Menurunnya Pendapat Masyarakat karena Pandemi Covid-19 Membuat Bisnis Makanan dan minuman di
Cavinton Hotel mengalami penurunan. Daya beli masyarakat yang menurun akibat penurunan pendapatan dan adanya Aturan social distancing (menjaga jarak), membuat konsumen lebih berhati-hati dalam berbelanja secara langsung, sehingga membuat Restoran sepi pengunjung.

2. Pesaing Banyaknya Hotel/ Restoran yang terdampak akibat pandemi covid19, mengakibatkan strategi bisnis yang dilakukan mudah ditiru oleh pesaing, Hotel/Restoran berjuang keras untuk bisa bersaing dengan pengusaha daring, dan pandemi korona merubah kebiasaan masyarakat, dari luring ke daring atau penjualan dari offline menjadi On line.

\section{Strategi Pemasaran}

Tidak dapat dipungkiri pada masa pandemi seperti ini pemasaran merupakan salah satu kekuatan pada bisnis Hotel dan Restoran. Manajemen Hotel berusaha agar Hotel/ Restoran dapat menghasilkan pendapatan di masa krisis ini. Strategi Pemasaran yang dilakukan oleh Hotel/restoran di Cavinton Hotel Yogyakarta tidak terlepas dari Seperangkat alat pemasaran yaitu Place, product,Promotion, Price, People, Physical evidence dan Process.

\section{Lokasi ( Place )}

Lokasi Cavinton Hotel Yogyakarta sangat Strategis berada di pinggir jalan utama menuju nol kilometer pusat yogyakarta, dekat dengan kawasan wisata kraton, belanja dan museum.

\section{Produk (Product)}

Produk makanan dan minuman yang dihasilkan oleh F\&B Produk dijual dalam bentuk paket yang menarik untuk menarik pembeli. Menu yang menarik untuk pelanggan yang ada dirumah, Konsumen dapat memilih menu yang ditawarkan melalui website maupun media sosial. Menu yang ditawarkan yaitu, Menu Utama, Camilan dan Minuman. 
Memberikan Variasi menu merupakan salah satu Strategi Food and Beverage Hotel bertahan di masa Pandemi ini.
Kemudian ada kafe yang berada di basement menawarkan berbagai makanan dan

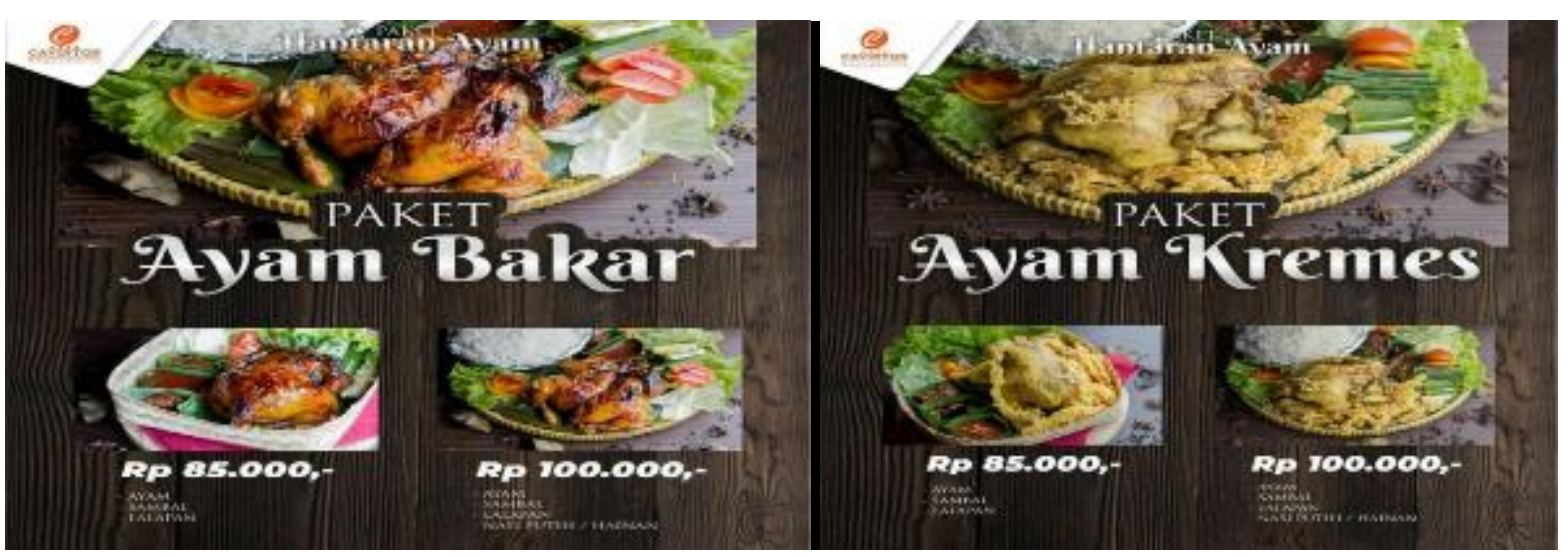

Gambar 1. Produk Makanan

Sumber : Instagram Cavinton Hotel Tahun 2020

\section{Promosi (Promotion)}

Strategi yang dilakukan oleh Food and Beverage produk yaitu dengan Promosi, Promosi diperlukan agar masyarakat mengenal akan produk yang ditawarkan dan Untuk memberikan informasi yang lengkap dan akurat tentang produk yang ditawarkan kepada konsumen , Promosi dilakukan dengan menggunakan
Social Media yang sering digunakan oleh Masyarakat seperti Instagram, Facebook, Whats app dan melalui web site ipiring. Promosi yang dilakukan juga dengan memberikan potongan harga kepada konsumen. Promosi juga dilakukan dengan menawarkan Paket wedding, Unniversary, pada masa pandemi ini tentu saja dengan mematuhi protokoler kesehatan.

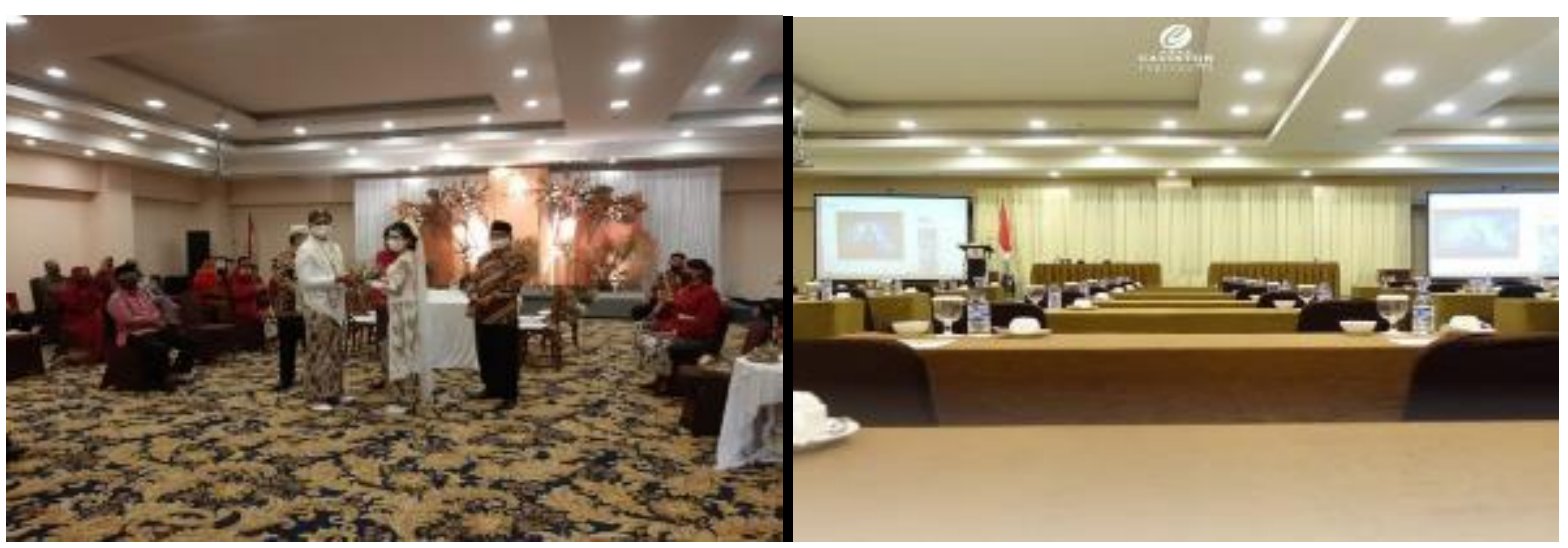

Gambar 2. Paket Acara Meeting dan Pernikahan

Sumber: Cavinton Hotel Yogyakarta tahun 2020

\section{Harga (Price)}

Harga yang ditawarkan sangat beraneka ragam sehingga dapat dijangkau oleh konsumen. Mulai dari Rp. 20.000 sampai dengan Rp. 100.000 untuk makanan dan Rp. 5.000 sampai 20.000 untuk minuman. Produk ini dapat dipesan dari jauh hari dan sesuai dengan jumlah kebutuhan pelanggan. Selain itu juga ada pengantaran gratis, sehingga pembeli tidak perlu keluar rumah. Dengan demikian social distancing dapat berjalan dengan baik. 


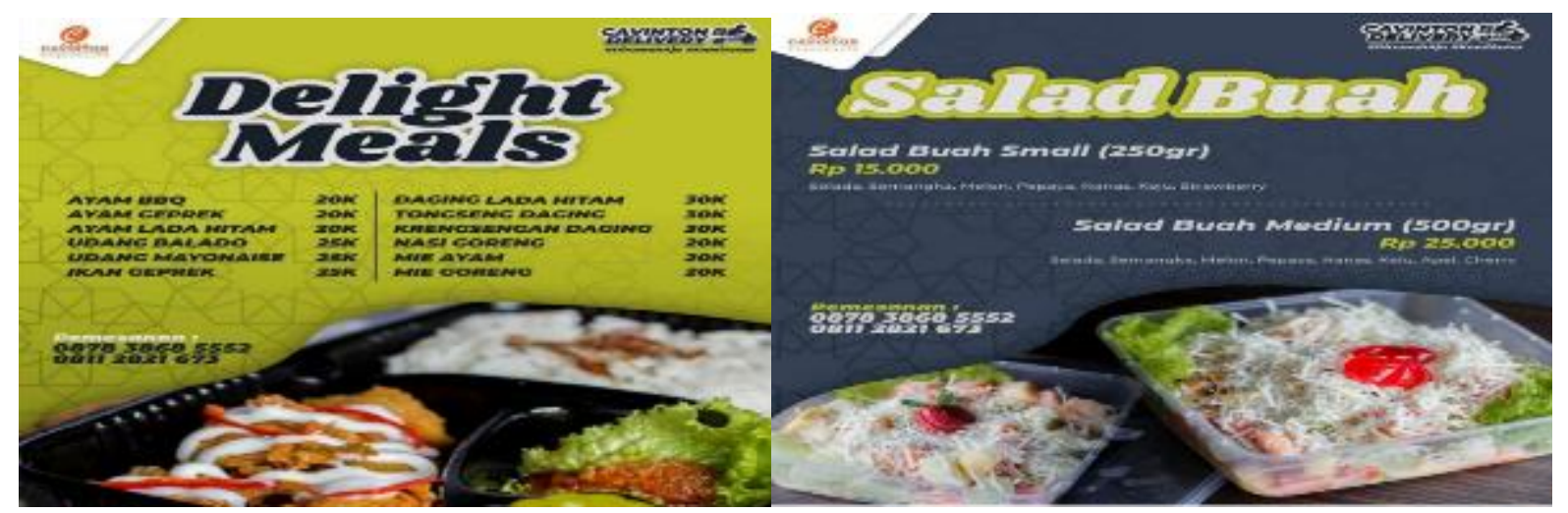

Gambar 3: Daftar Harga menu

Sumber : Cavinton Hotel Yogyakarta tahun 2020

\section{Orang (People)}

Pelayanan kepada tamu memenuhi Protokol kesehatan yang ditetapkan pemerintah. Karyawan harus Menjaga kesehatan pribadi dan menjalankan prosedur kesehatan covid 19. Menggunakan pakaian khusus kerja dan mengganti pakaian saat selesai bekerja. Pada saat bekerja, bila perlu gunakan alat pelindung diri seperti sarung tangan serta pelindung mata dan wajah terutama. Karyawan melakukan pengecek suhu tubuh, Melakukan pembersihan dan disinfeksi secara berkala di area kerja dan area publik

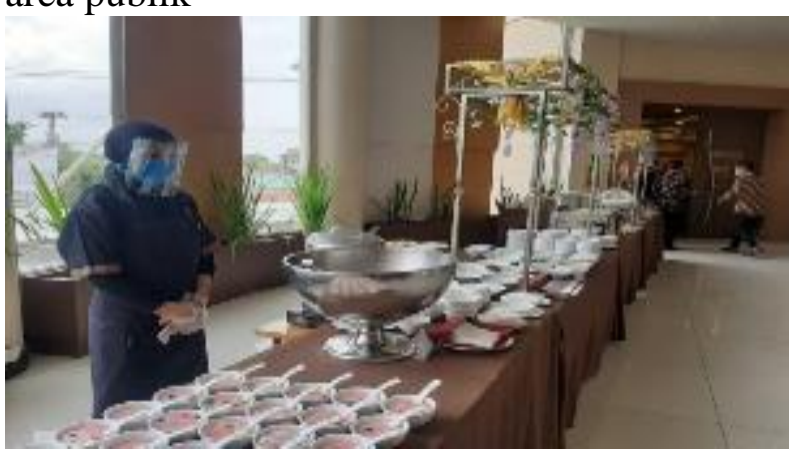

Gambar 4. Grooming Karyawan Di masa Pandemi Covid-19

Sumber : Cavinton Hotel Yogyakarta tahun 2020

\section{Tampilan Fisik (Physical Evidence)}

Dengan adanya Verifikasi protokoler Kesehatan Pemerintah Kota Yogyakarta merupakan bukti fisik bahwa cavinton Hotel Yogyakarta telah memenuhi syarat protokolol pencegahan dan Pengendalian Covid-19. Hal ini menjadikan kepercayaan bagi Konsumen /Tamu di cavinton Hotel

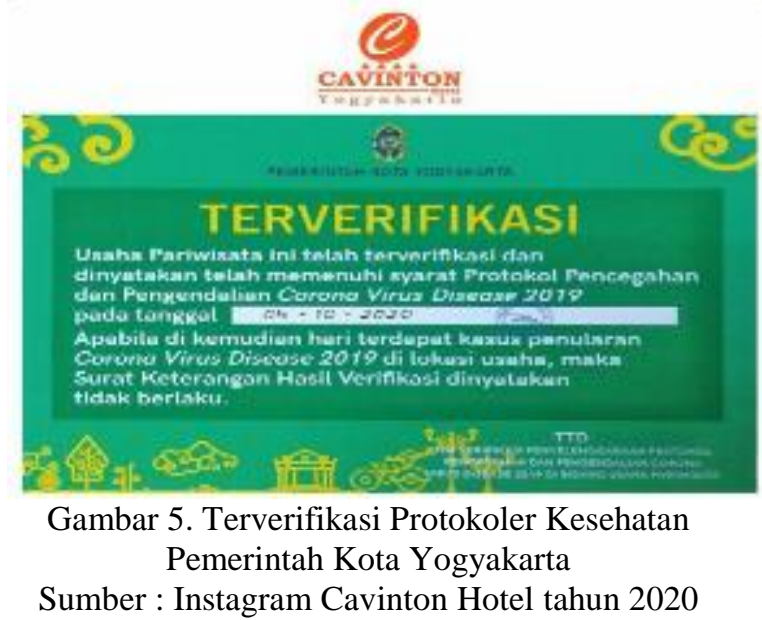

\section{Proses (Process)}

Proses pemasaran dalam Food and Beverage Departement dalam memasarkan produk dimasa pandemi covid 19 harus kreatif dan inovasi dalam memuaskan keinginan konsumen. Social Media dan internet merupakan sarana pendukung dalam proses pemasaran. Penggunaan media sosial dan Internet Merupakan salah satu cara menarik minat masyarakat terhadap produk Food and Beverage Hotel Cavinton.

\section{KESIMPULAN}

Dari penelitian yang telah dilakukan diatas dapat ditarik kesimpulan sebagai berikut :

a. Akibat Covid-19 membuat kesadaran Masyarakat akan kebersihan, kesehatan, keselamatan dan kelestarian lingkungan sangat besar, 
sehingga hotel Cavinton lebih memperhatikan kebersihan , keselamatan dan kelestarian lingkungan untuk pelanggan sehingga Konsumen percaya dan merasa aman akan produk yang dihasilkan oleh Food and beverage Cavinton Hotel

b. Terpuruknya sektor Pariwisata akibat social distance menyebabkan bisnis perhotelan terpuruk sehingga Food and Beverage menggunakan Berbagai Inovasi dan Strategi agar dapat bertahan pada masa Pandemi Covid19. Hal ini membuat Cavinton hotel menggunakan berbagai strategi penjualan baik online maupun offline

c. Usaha F\&B Cavinton Hotel dalam meningkatkan penjualan yaitu melalui layanan pesan antar mengingat Minat Masyarakat terhadap makanan layanan antar semakin diminati, karenan meningkatnya penularan covid-19 membuat masyarakat membatasi diri untuk keluar rumah.

\section{DAFTAR PUSTAKA}

Thamrin, Abdullah dan Tantri, Francis. 2016. Manajemen Pemasaran, Depok: PT. Raja Grafindo Persada

Agus Mertayasa, I Gede. (2012). Food and Beverage Service Operational. Yogyakarta: Andi.

Amaliya, Anis Halimah. 2017. Skripsi: Pengaruh harga dan biaya promosi terhadap volume penjualan emas (Studi kasus pada pegadaian Syariah cab Botanical Junction). Jakarta. UIN Syarif Hidayatullah

Atmoko, Presetyo Hadi. (2018). Strategi Pemasaran untuk meningkatkan Volume Penjualan di Cavinton Hotel Yogyakarta, Journal of Indonesian Tourism, Hospitality adn Recreation Vol. 1 No. 2 Oktober 2018

American Marketing Association, "About AMA: Definition of Marketing," $<$ https://www.ama.org/AboutAMA/P ages/Definition-of-Marketing.aspx $>$ (dikutip pada 28/11/2020)
Darmadi,Didik. 2013" Pengaruh Promosi Penjualan Terhadap Penjualan", Jurnal Administrasi Bisnis (JAB) Vol.2 N0.1 Hal. 21-28

David, Fred R. (2011). Strategic Management: Concept (12th Edtiton), New Jersey: Pearson Education Inc.

Kurniadi, Firmansyah. 2010. Pengaruh Biaya Promosi dan Distribusi terhadap Peningkatan

Volume Penjualan pada CV. Sejati Sragen. (Fakultas Ekonomi Universtas Muhammadiyah Surakarta. Surakarta. Skripsi.

Gorbalenya, Alexander E. 2020. "Severe acute respiratory syndrome-related coronavirus - The species and its viruses, a statement of the Coronavirus Study Group". bioRxiv (dalam bahasa Inggris):

2020.02.07.937862. doi:10.1101/202 0.02 .07 .937862 .

Hendriyati, Lutfi. 2020. Upaya Masyarakat di Desa wisata Penglipuran Dalam menjalankan Sapta Pesona, Journal Of Tourism and Economic Vol.3,No.1,2020, Hal 49-57

Kotler, Philip dan Gary Armstrong, 2012. Principles Of Marketing, Edisi 14, New Jersey: Prentice-Hall Published

Kotler, Philip and Kevin Lane Keller, 2016. Marketing Management, 15th Edition, Pearson Education,Inc.

Mukhtar 2013. Metode Praktis Penelitian Deskriptif Kualitatif, Jakarta Selatan: Referensi (GP Press Group)

Prihandini, Niken dan Mayasari, Citra Unik. (2019). Penerapan minimum charge untuk outside guest restoran di Amanjiwo Resort, Journal of Tourism and Economic Vol.2 No. 12019 Page $1-9$

Sugiyono. (2017). Metodelogi Penelitian Kuantitatif Kualitatif dan R\&D. Bandung: Alfabeta 
Thamrin, Abdullah dan Tantri, Francis. 2016. Manajemen Pemasaran, Depok: PT. Raja Grafindo Persada

Utama, Rai dan Mahadewi. (2012). Metodelogi Penelitian Pariwisata dan Perhotelan, Yogyakarta : Andi Offset
"WHO Director-General's opening remarks at the media briefing on COVID-19 - 11 March 2020". www.who.int (dalam bahasa Inggris). Diakses tanggal 2020-1130.

https://www.kemkes.go.id/folder/view/full -content/structure-faq.html diakses 30/11/2020 